\title{
Name changes and visions of 'a new Jew' in the Helsinki Jewish community
}

\author{
LAURA EKHOLM and SIMO MUIR
}

\begin{abstract}
T his article discusses an organized name-change process that occurred in the 1930s in the Jewish community of Helsinki. Between 1933 and 1944 in approximately one fifth of the Helsinki Jewish families (c. 16\%) someone had their family name changed. We argue that the name changes served two purposes: on the one hand they made life easier in the new nation state. It was part of a broader process where tens of thousands of Finns translated and changed their Swedish names to Finnish ones. On the other hand, the changed family names offered a new kind of Jewish identity. The name-changing process of the Helsinki Jews opens a window onto the study of nationalism, antisemitism, identity politics and visions of a Jewish future from the Finnish perspective.
\end{abstract}

Names are individual and collective signifiers. We are identified as individuals by the combination of our given and family names. Simultaneously names carry connotations of a linguistic, religious and social background; thus names also denote membership and are an expression of belonging to a collective. Most certainly names affect the lives of the people carrying the names. Hence, naming patterns and ideas connected to names provide an intersection for analysing both individual and collective aims at once.

In this article, we will examine a relatively short period between 1933 and I 944 when many Jewish families in Helsinki had their surnames changed. We ask why did some Jewish families change their family names? What were their motivations?

There are lots of anecdotes relating to the arbitrary history behind Jewish family names. In Imperial Russia Jews were given family names by local authorities; a clerk behind a desk ascribed a proper name to a man who yet did not possess one (Verner 1994). To give one example, a common name for Jews in Russia was Besprosvannij, which literally translates into 'holds no name', as it was given by a military recruiter to a conscript who did not posses a name. ${ }^{1}$

1 This is a family anecdote from Helsinki Jewish community but also mentioned by Andrew M. Verner (1 994). 
Similarly, the mass migration from Eastern European Jewish homelands to the Americas meant that a new name was chosen or given ad hoc upon immigration to a new country. Abraham Stahl (I994) has noted that in the early years of modern Israel it was a common practice to impose Hebrew first names, but sometimes also family names upon immigrants. All in all, receiving the family name was an arbitrary process in which the receiver of the name often played a passive role.

The literature on name changes among European Jews approaches the theme through the framework of assimilation. According to Tamás Farkas (2012) the mass Magyarization of the Jewish names in Hungary from the mid-nineteenth century until $\mathrm{I} 938$, for example, served as a means of fully assimilating them into Hungarian society. Neology (Reform Judaist) communities especially aimed to become Hungarians according to the Mosaic faith (Frojimovics 2003). James Jacob and Pierre Horn (I998: I3-I 5) have noted that in post-WWII France most names that were changed were foreign-sounding names, and especially family names that sounded 'Jewish', were 'Frenchified'.

In this article, we study an organized name-changing process in which the Jewish community promoted individuals to have their names fashioned according to nationalistic visions. While the decision to change a family name took place on an individual initiative, the local Jewish congregation was involved in selecting and approving the new names. Moreover, the process can be seen as part of a broader name-changing campaign in Finland. Therefore, the name changes facilitate an analysis of the interplay between individual motivations and collective visions of a Jewish future from a Finnish perspective.

To change one's name is a controlled and regulated procedure in modern societies and there are thus extensive sources to be consulted on what kinds of names people have wanted to change.

Name change in Finland was supervised by the County Administrative Boards (Fi. lääninhallitus, Swe. länsstyrelse), which consulted various other institutions, including Suomen Sukututkimusseura (the 'Genealogical Society of Finland'). Such institutions indicated whether or not the name should be considered suitable for Finnish language and that the name was not already in use. If a Swedish-speaking person wanted to change his/her name, the Swedish section of the Genealogical Society of Finland would undertake the evaluation.

The boards of the Jewish communities in Finland had a chance to regulate the name changes, as the County Administrative Board sent the name applications to them for approval. We have collected the original names from Judisk årsbokfor Finland 1930 (Jewish yearbook; in Swedish). We then use the protocols of the Board of the Jewish Community of Helsinki, I933-44 (Finnish 
Jewish Archives, National Archives of Finland) to see how many names were changed, in which years.

Due to the small numbers in the Helsinki Jewish community there is no need to take samples. For the same reason, we prefer not to publish lists of all the names changed, although name changes as such are public information and announcements of changed names can be found in contemporary newspapers.

To understand the aims of those who organized the name changes and to set the process into a broader social context, we use published guides on suitable names. Organizations such as Suomalaisuuden liitto (the 'Association of Finnish Culture and Identity') published guides with recommendations for suitable Finnish names. The Palestine Department of the Jewish community of Helsinki published their own guidelines.

\section{The Helsinki Jewish community in the interwar period ${ }^{2}$}

By the I 930 s there had been Jewish families living in Helsinki for a century. The first Jewish families living permanently in Helsinki arrived in the I8zos. The Jewish communities in Helsinki (Helsingfors), Turku (Åbo) and Viipuri (Viborg) got organized and institutionalised three decades later, in the r 860 s (Ekholm 2013: 49-52). 3 The community remained small due to Finland's explicitly restrictive Jewish policy, which aimed to keep the communities as small as possible (ibid. 53-9).

Autonomous Finland banned Jewish subjects from staying in Finland, and Jews could get a residential permit only when serving in the Imperial Russian army. The status of Jews in Finland was debated from the I 870 , yet Jews were granted civil rights only with Finland's independence at the end of I9I7. The debate on Jewish civil rights follows typical patterns of nineteenth century antisemitism, with all of its inherent contradictions included; the fear of an invasion of 'Jewish masses' from Eastern Europe combined with the fear of a powerful Jewish network taking over the nascent Finnish domestic markets.

In the interwar period, there was no longer any legal discrimination against Jews. Those Jewish families who had residential permits in Finland were able to apply for Finnish citizenship.

2 For a brief history of the Jewish communities of Finland, please visit an online exhibition Fenno Judaica (see the list of references).

3 When parts of Finnish Karelia and Viipuri were annexed by the Soviet Union as part of the Moscow Armistice in I 944 a new Jewish community was soon established in Tampere with former members of the Viipuri community. 
From the point of view of local Jewish life in Finland, the youths growing up in the interwar period were often second or third generation citizens of Helsinki, Turku or Viipuri, yet were the first generation in their families to enter adulthood as Finnish citizens. The Finnish Jewish community maintained Orthodox Jewish traditions and were Zionist-oriented.

There were around 200 households and less than 2,000 individuals in the three Jewish congregations of interwar Finland (Judisk årsbok for Finland 5690-1930). Despite the small size of the community there was a very active cultural life. In addition to religious services the Jewish community of Helsinki maintained a Jewish co-educational school (Muir 2004: 8 I-IOO). There were several Jewish associations and organizations for different age groups (ibid. 47-76). The young could do sports in a Jewish sport club Makkabi, join the Jewish scout club Kefir, or join the Jewish choir or theatre group, amongst other things. (ibid. 67).

At the same time, in many respects the Jewish youth resembled their peers - other young people from middle-class backgrounds in Helsinki: after Jewish school they continued to high schools, many used a nick name reminiscent of those favoured by Helsinki youths, whenever they were allowed to join, many young Jewish men were eager to participate in paramilitary defence organizations (Fi. suojeluskunta, Swe. skyddskår) (Jakobsson I 999: I 86; Ekholm and Muir 20I I: 45).

Civil rights reforms changed the legal position of Finnish Jews, but there is no doubt that Finnish society at large continued to consider Jews to be a 'foreign element'; Jews were not considered to be part of the young nation state. There were deep-rooted prejudices and fears concerning (imaginary constructions of) Jews. In a Christian country, the 'image' of Jews was constantly present (Myllykoski and Lundgren 2005). Thus the idea of Jews was present even without any real connection to Jewishness.

There were fears that 'Jewish masses from the East' would find their way into Finland. An even more common concern was the ominous image of cunning Jewish businessmen with their all-powerful networks who would overrun the nascent Finnish domestic markets (Ekholm 2013: 59). And finally, a fear of Bolshevism blended with antisemitism. The impression that Jews were involved in the making of Soviet-Russia was very widespread and a commonly-held view in Finland (Silvennoinen 2009: 2 I 5-I 7). Russophobia or antisemitism? In many cases, it is impossible to distinguish between the two: perceptions of the enemy contained both aspects.

Jews in Finland were not just an ethnic or religious minority. They were generally associated with 'Russians', although most of the families came from 
the Pale of Settlement (comprised of western areas of the Russian Empire). Furthermore, linguistic changes went from Yiddish (and in some cases Russian) to Swedish, which until the r 9 Ios was the most commonly-spoken language in Helsinki (Muir 2009a). Consequently Jews in Finland were not only a religious and ethnic minority but also a linguistic minority, even if they adopted a local language. As elsewhere in the border regions of Eastern Europe, the language struggle became a burning political question in late nineteenth-century Finland.

\section{The language question becomes a name question}

In Finland Swedish was traditionally the language of the elite, industry, higher education and politics, whilst the majority of the population, apart from that of the coastal areas, had Finnish as their native tongue. In this sense, Swedish had a similar position in Finland as German had, for example, in Latvia and Estonia.

Naming practices varied within the country. The family names of noble families and the bourgeois were mostly Swedish or Germanic. Fixed family names had been known since late medieval times in eastern Finland while in western Finland both Finnish and Swedish speaking people were often called by the names of the houses they lived in. Thus if a person moved to a new house, the common practice was to give him or her a new name accordingly. The landless population in the countryside, especially, lacked fixed surnames.

The experience of a person without a fixed family name would be quite similar whether they were in the Russian or Finnish countryside. In large part the Eastern European landless population family names were ascribed by the local authorities - by a parish priest or clerk behind a desk who would decide upon a proper name for a man without a family name. Names could be misspelled because authorities did not necessarily master the vernacular of the local majority. It was not uncommon for a Finnish priest to write Swedish names into the parish books. There are number of anecdotes for brothers who each adopted a different family name upon arrival in rapidly industrializing towns, in order to find jobs. According to oral history, the local priest or teacher decided what kinds of low-profile names were proper for country folk (Mikkonen 20I3). There were also priests who persistently gave Swedish sounding names in completely monolingual parishes or employees who required their employers to have Swedish names; even changing Finnish names into Swedish ones (ibid. I $30-2){ }^{4}$ 
The law on surnames (Fi. sukunimilaki, Swe. lag om antagandet av släktnamn) made fixed family names obligatory in Finland as late as in I92 I. By comparison, Jews in the Russian empire, for example, had already been required to adopt surnames in 1804 in order for the state to be able to control, and later, after I 827 conscript the Jewish subjects and collect their taxes (Avrutin 2005: 136). The Jews of the Habsburg Empire had been decreed to have a Germansounding family name since 1789 (Silber 2010).

This belated legislation in Finland did not mean that there was an absence of strong feeling concerning the issue of names used in the country. Names are naturally one of the core interests of any nationalistic movement, and this proved to be the case also in Finland. Many scholars in the late nineteenth century and the early twentieth century were devoted to finding real, original Finnish-language name-types.

In the late nineteenth century attention was given to practical questions, such as difficulties among the Finnish population to use and write names that were foreign to Finnish pronunciation. In addition to purely practical matters such as efficient, modern state administration, issues concerning a strong, shared national identity were emphasized. A shared family name would bind a family together in the same way that a shared language was thought to bind a nation (Paikkala I999: I 28). Scholars did not value the variations of naming patterns and traditions through history. Instead a general theory was promoted according to which the west coast of Finland had originally possessed an ancient naming-system that would have been corrupted and eventually forgotten under Swedish rule (ibid. I28).

In Finland a significant number of the ruling elite or upper strata decided to change their native language from Swedish to Finnish (Haapala 1995: I22-4). Parallel to the decision to take Finnish as the language of the family came a decision to change the family name into a Finnish-language form. Consequently, a major proportion of eminent Finnish authors, artists, politicians and scholars from the late nineteenth and the early twentieth century are known by their adopted Finnish names, instead of their original Swedish-language names.

By the early twentieth century, there were two elites in Finland; besides the traditional Swedish-speaking elite there was now a Finnish-speaking elite (Haapala 1995: I24). Family names became one manifestation of this division. Mass campaigns were arranged to help people to reach this goal. 


\section{6 and 1935 mass campaigns for name changes}

The first mass campaign to change family names from Swedish to Finnish took place in 1906 (Paikkala 2004: 502-8). It was organized by the Association of Finnish Culture and Identity. Students at the University of Helsinki, especially members of an extreme right-wing student movement, Akateeminen Karjala-Seura (AKS, 'Academic Karelian Society') played an active role in this process (Kortti 2009: 8-II). The year I 906 was the centennial jubillee of a nineteenth century statesman J. V. Snellman, who became a celebrated national figure, the 'father of the Finnish language program' (Paikkala I 999: 1 27). It has been estimated that some 70,000 Finns had their Swedish family names Fennified (Paikkala 2004: 5 14-22). For a country of c. 2.8 million inhabitants these were impressive numbers.

How did Helsinki Jews react to the nationalistic movement? The community activists within the Helsinki Jewish community dedicated themselves to questions of identity: what were the Finnish Jews like? What was the role of the Finnish Jews in the Jewish world? The community looked for ways to combine (an Orthodox) Jewish life with the calls of modern society in an increasingly nationalistic environment.

The language struggle itself was something that applied to Helsinki Jews in two ways: Firstly, the role and position of Finland's Swedish-language population and institutions was a question of great importance throughout the I 920 and the 1930 in the new nation state (Kortti 2009). A movement called Aitosuomaiset ('Genuine Finns') strove to displace Swedish speakers from any prominent position in Finnish society. In the most aggressive rhetoric, the Swedish speaking population of Finland would even be referred to as the "Jews of Finland' (Grünstein r 988: 4I).

Secondly, the Jewish world had its own language dispute; that between the old European Jewish vernacular, Yiddish, and the revived and recreated ancient language of the Holy Scriptures, Hebrew; and Jewish communities were shifting with growing speed from Yiddish to speaking the dominant languages of the countries they lived in (Muir 2009a; e.g., Katz 2004).

A second boom of name changes in Finland started in 1935, when Finland celebrated the centennial of the national epic Kalevala. This time the process was state-led. To promote the possibility of a new, 'genuine' Finnish name the law was changed for the period of 1934 to 1936 to make the name-changing process easier for Finns ('Laki nopeammasta menettelystä sukunimen muuttamisessa', no. 30I/r 934; Paikkala 2004: 525). The organizers counted that more than, " $[a] 11$ in all, a total of 74,064 individuals participated in the name changes 
to celebrate the Kalevala Jubilee' (Suomalainen Suomi I 936: I30-I, translated from Finnish by the authors).

Considering the Russophobic and antiSoviet atmosphere of the interwar period, when the country was recovering from a fierce civil war, it is not surprising that many Russian family names were changed. This was also the period, when Jewish name changes began in Finland.

The Jewish name changes started at a time when the Helsinki community decided to change the language of instruction of the

\begin{tabular}{|l|r|}
\hline Years & Changed names \\
$1933-4$ & 2 \\
$1935-6$ & 10 \\
$1937-8$ & 3 \\
$1939-40$ & 5 \\
$1941-2$ & 10 \\
$1943-4$ & 4 \\
\hline Total & 34 \\
\hline
\end{tabular}

Source: Protocols of the Board of the Jewish Community of Helsinki, 1933-44; Judisk årsbok för Finland 5690-1930. Jewish co-educational school from Swedish to Finnish (Muir 2004: 99-Ioo). In the wake of the intensifying language strife the Jewish community, especially the young members, felt that it was too onerous to belong to a double minority; that is, to be both Jewish and Swedish speaking. The Jewish school was fully Finnish speaking by I94 I, but the children continued to speak Swedish (and Yiddish) at home.

As the table shows, the first Jewish family name changes appeared in I933 and continued to I945 with a couple of peaks; one in I935-6, the Kalevala Jubilee and another in I94I-2, a turbulent period when Finland was de facto allied with the Third Reich in a war against a common enemy, the Soviet Union. The table gives the number of names changed; however, it does not mean that everyone with the same name chose to have a new name.

The second peak was noted by an antisemitic periodical Uusi Eurooppa ('New Europe'). It paid attention to changed Jewish names arguing that Jews were trying to disguise their identities (Uusi Eurooppa r 943). The line of the argument, delivered in an ironical tone, reveals one feature of modern antisemitism; the idea that Jews pose a danger to society by blending in, making it impossible to distinguish Jews from non-Jews (Bauman 2000: 2 I 9-20).

The ethos among the active community members in the Helsinki Jewish community was, however, strongly against any kind of blending in. The visions attached to the new Jewish names rather reflected a cultural project of creating a 'New Jew' - a certain kind of counter-image to antisemitic stereotypes. The new Jewish character would be athletic, nationalistic and practical. ${ }^{5}$ It is thus no coincidence that young Jewish men in Helsinki were eager boxers, wrestlers and 
sprinters (Ekholm and Muir 20I I: 45). The community awarded scholarships to young students to study 'useful' subjects such as agriculture (Ekholm 2013: 70). Such hobbies are reminiscent of activities associated with Max Nordau's Muskeljude (Stansilawski 200 I, Mosse I 999).

A new Jew would no longer represent any kind of foreign element in society, rather he or she would be an active subject that held the future in his/her own hands. From the point of view of the Jewish community, the new Jewish names were designed to support these broader objectives.

Some of the interwar Zionist organizations in Finland oversaw matters concerning emigration to Palestine. Aid organizations such as Keren Kayemeth le-Israel, Keren Hayesod and the Women's International Zionist Organization (WIZO) collected money for Jewish colonies in Palestine (Torvinen I 989: I I $)$. The central Zionist association Hamerkas Hazioni b’Finland was established in 1932 (website of Fenno Judaica: Kultur, Sionistiska föreningar).

A majority of the Finnish-Jewish Zionists held moderate political opinions but there were also supporters of radical revisionists as well as some whose sympathies tended towards the Zionist left. Notably, there was no organized form of leftist opposition of Zionism among the Finnish Jews.

The name changes started to take place when Rabbi Simon Federbusch, an influential Mizrahi Zionist leader from Poland, was nominated Chief Rabbi of Finland in I 934. Mizrahi Zionism combined Orthodoxy and Zionism, and this became a trend which was followed by the Jewish community of Helsinki (Edelmann and Muir 20I0). The Jewish community of Helsinki adopted the policy that new names had to have a Hebrew meaning.

\section{Finnish and Jewish new names, practices and ideas}

Finnish society in the interwar period did not approve of bilingual identities - the vision was to be able to neatly categorize and organize all citizens according to linguistic compartments.

The ideal was that a Finnish person could also show which part of the country he came from, so as to give a name that would reflect the distinctive Finnish family lineage. This comes up when looking at the pattern of changing Swedish names into Finnish ones in contrast to the names given to Finns who simply did not yet have any family name. The 'Fennified' names often follow a pattern where one can still recognize the original name and its prestige. Giving a new name to people from the landless peasant population was a different process (Mikkonen 2013: 102). 
The rising, nationalistic Fennoman movement sought to use genealogical studies to reconstruct the 'original names'. The adoption of traditions could be quite selective. The tradition in eastern Finland according to which married women kept their patronymic name was seen as problematic and un-modern. The typical suffix '-(i)nen', used in eastern Finland, was adopted as a recommended form for a genuine Finnish family name. A western-Finnish style Finnish name was formed using similar themes but without any suffix and was adopted especially in the r89os (Paikkala r999: 132). In the making of new Finnish family names, the themes were often taken from nature: flora, soil, or natural phenomena in general (ibid. I 29).

The organizations promoting Finnish language names published leaflets and newspaper lists of good and proper Finnish names. While the earliest lists collected for the I 906 campaign listed all kinds of names (see e.g., Koskimies I907), the later lists gave more emphasis to differences between eastern and western Finnish name traditions.

The ideological background of the language enthusiasts becomes most evident when one looks at the suggested names for East Karelians for the period when the Finnish forces had occupied the area during the Second World War (from summer I 94 I to summer I 944). East Karelians were supposed to change their Russian names into Finnish ones, but to such names that would still distinguish them as East Karelian Finns, not to be confused with other Finns. This comes up in a brochure published by the Association of Finnish Culture and Identity in 1942 which aimed to 'give guidelines for East Karelians who chose a new surname and thus furthered the rapprochement of East Karelian tribes for uniting with the rest of Finland'(Teppo I 942). East Karelians were recommended to change their Russian names to a Finnish form. If that was not possible, the booklet suggested a direct translation or the adoption of a name that 'was short and adaptable to a Karelian environment'. Interestingly, however, the booklet did not recommend name types that were typical of western Finland for East Karelians. Although this was only stated in passing and overall it was meant to be an inclusive policy, this reveals an underlying vision of a society where ethnic backgrounds were not to be mixed.

What about the Jewish names, then? The Board of the Jewish Community of Helsinki discussed each name individually and in most cases approved the suggested change (Protocols of the Board of the Jewish Community of Helsinki, I933-44).

The main principle of the Jewish community was that Jews were not allowed to take a Finnish name or a name with a Finnish or Swedish meaning. As long as a Jew belonged to the Jewish community he or she could not adopt 
a Finnish name; only resigning from the community would have made this possible. Possibly discussions of a suitable name had already been taken place beforehand with leaders of the community and with specialists in the Hebrew language. There were also lists of Hebrew names circulating in the community.

There were two models for constructing the new Jewish names. Often the name appears just to have been shortened, as in Besprosvanni > Vanni, or Matsoff > Matso. In its new form the name would be easy to pronounce and spell. Furthermore, it worked both in Finnish and in Swedish contexts. However, after taking off the Slavic ending in the latter case the name achieves a new Hebrew meaning. In the Ashkenazi pronunciation, the word matso means unleavened Passover bread, matzah.

Another way was to adopt a name that somehow resembled the original name but was in fact a totally new name and new word with a Hebrew meaning. A good example of this is the change of Jankelow to Jaari. The new name sounds and looks very Finnish, without meaning anything, but it has a meaning in Hebrew that alludes to the word ya'ar, 'forest'. The name change was successful in several ways. First it got rid of the stigmatized 'Russian' ending '-ow/-off', secondly it also disguised the stereotypical Eastern European Yiddish male first name Yankl (diminutive of Yankev, Jacob). The new name also possessed desirable connotations to agriculture and nature which, at least in terms of Zionist thinking, diverted attention from the shtetls, the poor, murky and stagnated Jewish 'ghettos' of Eastern Europe.

Some name changes were not as successful as the case of Jaari however, either from the Finnish or Zionist point of view. Many names did not blend into Finnish so well. Interestingly, the Genealogical Society of Finland seemed not object to them, although similar names for other Finns would most certainly have been rejected (records of name changes of the Genealogical Society of Finland 1922-65). In other cases, the name perhaps suited Finnish well, but the Zionist leaders of the Jewish community were unsatisfied with some of them, considering them to be clumsy and tasteless. This is why in I943 the community's so-called Palestine Department published guidelines for changing names (Schur and Chosid I943). This publication coincides with the Finnish Jewish leadership learning about the annihilation of Jews taking place in Europe (Muir 2016, forthcoming). The Jewish community could continue its life uninterrupted but was, nevertheless, afraid of possible deportations. The Jewish leadership considered the prospects of Jewish life in Europe to be nonexistent and saw the only future to lie in a 'Jewish' Palestine. Efforts were concentrated on increasing Zionist education and preparations for Aliyah as soon as was possible (ibid.). 


\section{Motivation: antisemitism, Zionism or something else?}

There was obviously a Zionist dimension to the name changes, but to what extent was it an aspect of individuals' motivations to change names? This can be evaluated by looking at the names that were changed.

The community had three kinds of names; Slavic, Germanic and those of Hebrew origin. It would be reasonable to think that if the intentions were purely Zionist, then both Slavic and Germanic names would have been changed. In practice, almost all - clearly over ninety per cent - of the name changes occurred with names that were of Slavic origin or bore Slavic endings, as in the above example '-ow/-off', or '-sky/-ski'. Moreover, hardly any names of Germanic origin - such names as Weinstein, Grünstein and Manteuffel - were changed.

This would mean that the chief aim was to get rid of the Slavic stigma, and that anti-Russian resentment rather than simply antisemitism was behind the urge to change names.

The Slavic names were perhaps more complicated, and more difficult to pronounce and spell in an increasingly Finnish-language dominated atmosphere. The German names, by contrast, had a certain prestige attached to them as the Baltic-German pronunciation testifies (Muir 2009a).

During this period many Finnish families with Russian names decided to get rid of their Russian names. The most manifest forms of Finnish antisemitism of the r 930 were thus an organic part of anti-Russian resentment and anti-Bolshevism; purely racially motivated, National-Socialist antisemitism did not gain so much of a foothold.

The pattern to change family names had stopped by the end of WWII. There were naturally individual cases where someone had a name changed, but there are no longer any signs of an organized name-changing project. Despite the fact that Aliyah was the expressed goal of the community members and that the Israeli state preferred Hebrew names, Israel's declaration of independence did not trigger any new wave of name changes.

Hence, the motivation to change family names seems to have been triggered, after all, by trends in Finnish society. In some parts of Europe the position of people with Jewish backgrounds was so remarkable that having one's name changed was associated with Jewishness. For example Farkas (201 2: 6) has noted that Magyarization of names in Hungary was a Jewish trait.

In Finland, by contrast, 'half of the elite' had Fennified their names; the name change as such raised no associations. Those Jews who chose a new family name did not aim to translate their names into Finnish and efforts were rather made to find new names with a Hebrew meaning. 
One cannot draw too many parallels with the fierce campaigns between, on the one hand Finnish and Swedish language activists in Finland, and on the other questions concerning Jewish languages among European and world Jewry. As to the Finnish and Finnish-Jewish family names, there are however certain factors that interlink the two phenomena: the new names - Finnish and Finnish Jewish alike - were consciously made, yet the motivation for changing a traditional name into a new one was to locate imaginary, lost, ancient roots.

What is notable, however, is the new naming tradition concerning first names among Finnish Jews. The post-war/post-Shoah generation were given names such as Margalit, Aviva, Dan and Rony, breaking the traditional Hebrew and Yiddish name-giving traditions.

\section{Conclusion}

Much of anecdotal evidence and oral history on Jewish names reflects the arbitrary and spontaneous elements of the history of Jewish family names. Our analysis gives an example of a name-changing process which was supported by the local Jewish congregation.

Along with the rise of nationalism, the so-called language question became a vexed issue in Finland. As the enthusiasm to change Swedish names into Finnish ones demonstrates, a certain kind of ideology of order within the nation state was involved in the name changes (Paikkala I999: I 26).

As Russian citizens Jews in Finland were unable to respond to the first mass campaign to change Swedish names into Finnish ones in I 906. At that time, the main question for the local Jewish communities concerned the lack of civil rights for Jews. The situation looked different when the second name-changing campaign started in r 935. Most Jews in Finland now had Finnish citizenship, yet still were generally considered to be a 'foreign element'.

The new Jewish names provide a parallel case with the new Finnishlanguage names. In both cases there was a shared vision where the advisedly formed new names would connect people of the future with a bygone, and forgotten historical glory. To this end, themes taken from nature were favoured. Furthermore, both shared a certain kind of vision of order where each language group and people would have their own category in human history, for a 'new Jew', preferably in Israel, for Finns in Finland.

At the local level, Finns who desired to be taken seriously by 'stronger'nations could quite easily relate to Jewish belonging to a heroic Biblical past in Eretz Israel, the Land of Israel. When parts of the Finnish national epic the Kalevala were translated to Hebrew in the I930s, some Finnish commentators found 
connections between the Biblical past of the Jews and the Finnish 'Land of Kalevala' and by so doing upgraded Finnish history to be on a par with ancient civilizations (Muir 2009b: $35 \mathrm{I}-3$ ). In this new setting a Finnish Jew would no longer be a 'foreign element' but a necessary mediator between two modern, new nation states.

The name changes provide an opportunity to evaluate the interplay between collective visions and individual choices in the context of different kinds of nationalisms. Thus, while Zionist organisations and activists concerned themselves with the construction of a Jewish state, at the local, everyday level of the individual in Helsinki there was an ongoing effort to attain a position in society where one no longer had to negotiate between Finnishness and Jewishness - or rather deal with the connotations with Eastern European Jewish heritage that the Slavic names manifested.

Laura Ekholm is a postdoctoral researcher in the Department of Political and Economic Studies with a specialization in Economic and Social history at the University of Helsinki. Her PhD Boundaries of an Urban Minority: The Helsinki Jewish Community from the end of Imperial Russia until the 1970s (2013) examined the history of the Helsinki Jewish community. The study operationalised occupational status to analyse changes in the social position of the community. Supported with the findings of this empirical material she analysed and contextualised different aspects of what has been written down as Finnish-Jewish history.

Simo Muir is a postdoctoral research fellow in a project called Performing the Jewish Archive at the University of Leeds. Muir received his MA in Yiddish Studies at SOAS, University of London, and his PhD in Yiddish linguistics at the University of Helsinki in 2004, and has published widely on Jewish history in Finland, JewishFinnish relations, and latent antisemitism in Finland in the 1930s. Between 2010 and 2014 he was a researcher in the Finnish Academy-funded project Cultures of Silence, which focused on Finnish historiography of the Holocaust. Muir is a contributing co-editor of Finland's Holocaust: Silences of History (2013).

\section{References}

Archive sources

National Archives of Finland, Helsinki

Finnish Jewish Archives

Protocols of the Board of the Jewish Community of Helsinki, I 933-44

Genealogical Society of Finland

Records of name changes

Published sources and digital collections

Judisk årsbok för Finland 5690-1930 (Helsingfors, Oy Surdus Ab, 1929)

Koskimies, August Valdemar, I 907. Suomalaisuuden liiton nimiopas, I (Helsinki,

Yrjö Weilin) 
Laki nopeammasta menettelystä sukunimen muuttamisessa, no. 301/1934

Meliza's Genalogy. Meliza Amity's genealogical website, <http://www.amitys.com> (accessed I.I.2007-30.9.2010)

Suomalainen Suomi, 1936. 'Nimenmuuttotoiminta', Suomalainen Suomi, 2/r 936, pp. I $30-$ I

Teppo, Hannes, I 942. Itäkarjalaisten nimiopas (Helsinki, Suomalaisuuden liitto)

\section{Bibliography}

Avrutin, Eugene, 2005. 'The politics of Jewish legibility: documentation practices and reform during the reign of Nicholas I', Jewish Social Studies, I I (2), pp. I36-69

Bauman, Zygmunt, 2000. 'Modernity, racism, extermination' in Theories of Race and Racism. A Reader, eds Les Back and John Solomos (Oxford, Routledge), pp. 2 I $2-28$

Edelmann, Moshe, and Simo Muir, 20 ro. 'Federbusch, Simon (I 892-r 969). Helsingin juutalaisen seurakunnan rabbi, Suomen päärabbi' in Suomen kansallisbiografia II, (Helsinki, SKS)

Ekholm, Laura, 201 3. Boundaries of an Urban Minority: The Helsinki Jerwish Community from the End of Imperial Russia until the 1970s, PhD Dissertation, University of Helsinki, <https://helda.helsinki.fi/bitstream/handle/ror 38/4 Ioog/boundari. pdf>

Ekholm, Laura, and Simo Muir, 2o I r. 'Isänmaasuhteen rakentaminen "kansallisten" nimien avulla. Helsingin juutalaisessa seurakunnassa tehdyt sukunimien vaihdot I 933-1944', in Historiallinen Aikakauskirja, I, pp. 29-47

Englund, Anders, I 996. 'Den nya juden och den judiska exilen i Judisk Tidskrift I 933I 950', Nordisk Judaistik - Scandinavian Jewish Studies, I 7(I-2), pp. I-23

Farkas, Tamás, 20I 2. 'Jewish name Magyarization in Hungary', AHEA: E-journal of the American Hungarian Educators Association, 5, <http://ahea.net/e-journal/ volume-5-2012>

Fenno Judaica (an online exhibition), 2009. Judiska församlingen i Helsingfors. $<$ http://fennojudaica.jchelsinki.fi/ > (accessed 7.9.2015)

Frojimovics, Kinga, 2003. 'Jewish naming customs in Hungary from the turn of the twentieth century until the Holocaust', Hungarian Special Interest Group (H-SIG): A Jewish-Gen SIG, <http://www.jewishgen.org/Hungary/>

Grünstein, Boris, I 988. Jude i Finland. Galghumoristiska berättelser (Helsingfors, Söderström)

Haapala, Pertti, I 995. Kun yhteiskunta hajosi. Suomi 1914-1920 (Helsinki, Kleio) Jacob, James, and Pierre Horn, I 998. 'Comment vous appelez-vous? Why the French change their names', Names: A Journal of Onomastics, 46(I), pp. 3-28

Jakobson, Max, I 999. Väkivallan vuodet. 20. vuosisadan tilinpäätös, I (Helsinki, Otava) Katz, Dovid, 2004. Word in Fire: The Unsatisfed Story of Yiddish (New York, Basic Books) Kortti, Jukka, 2009. 'Ylioppilaslehti and the university's language struggle in the r $920 a$ and the I93os', Kasvatus ja Aika, 3(4), pp. 7-23 
Mikkonen, Pirjo, 20 I 3. "Otti oikean sukunimen”. Vuosina 1850-1921 otettujen sukunimien taustat, $\mathrm{PhD}$ Dissertation (University of Helsinki)

Mosse, George, I 999. 'Die Juden im Zeitalter des modernen Nationalismus' in Die Konstruktion der Nation gegen die Juden, ed. Peter Alter, Claus-Ekkehard Bärsch and Peter Berghoff (Paderborn, Wilhelm Fink Verlag), pp. I 5-25

Muir, Simo, 2004. Yiddish in Helsinki: Study of a Colonial Yiddish Dialect and Culture, PhD Dissertation (University of Helsinki)

- 2009a. 'Jiddišistä ruotsin kautta suomeen: Helsingin juutalaisten kielivaihdoista ja etnolektistä', Virittäjä. Kotikielen seuran aikakauslehti, 4, pp. 533-56

- 2009b. "'Oh, language of exile - woven of sorrow and mockery”: the Kalevala centennial jubilee as a bone of contention between Hebraists and Yiddishists', East European Jewish Affairs, 39(3), pp. 347-67

2016 (forthcoming). 'The plan to rescue Finnish Jews in I 944', Holocaust and Genocide Studies, I

Myllykoski, Matti, and Svante Lundgren, 2005. Murhatun Jumalan varjo. Antisemitsimi kristinuskon historiassa (Helsinki, Yliopistopaino)

Paikkala, Sirkka, r 999. 'Europäischer Nationalgedanke und finnische Familiennamen' in Onomastik. Akten des 18. Internationalen Kongresses für Namenforschung, Band III, Namensoziologie (Tübingen, Max Niemyer Verlag)

-2004. Se tavallinen Virtanen. Suomalaisen sukunimikäytännön modernisoituminen 1850-luvulta vuoteen 1921 (Helsinki, SKS)

Schur, Israel-Jacob, and Mordechai Chosid, I 943. Katalog över hebreiska släktnamn. Luettelo hebrealaisista nimistä (Helsingfors judiska församlingen, avdelning för Palestina äranden)

Silvennoinen, Oula, 2009. 'Suomalaisen antisemitismin luonteesta' in Hyljättiin outouden vuoksi. Israel-Jakob Schur ja Suomen akateeminen ybteisö, ed. Ilona Salomaa and Simo Muir (Helsinki, Suomen Itämainen Seura), pp. 67-92

Stahl, Abraham, I 994. 'The imposition of Hebrew names on new immigrants to Israel: past and present', Names: A Journal of Onomastics, 42(I), pp. 279-88

Stanislawski, Michael, 200I. Zionism and the fin-de-siècle: Cosmopolitanism and nationalism from Nordau to Jabotinsky (Berkeley, University of California Press)

Silber, Michael, 20 го. 'Josephinian reforms', YIVO Encyclopedia of Jerws in Eastern Europe <http://www.yivoencyclopedia.org/article.aspx/Josephinian_Reforms> (accessed 2.1 I.2015)

Torvinen, Taimi, I989. Kadimah. Suomen juutalaisten historia (Helsinki, Otava)

Uusi Eurooppa, I 943. 'Juutalaiset muuttavat sukunimiään', Uusi Eurooppa, I 3/I 943, p. 3

Verner, Andrew, 1994. 'What's in a name? Of dog-killers, Jews and Rasputin', Slavic Review, 53(4), pp. 1046-70

Wasserstein, Bernard, 20I 2. On the Eve: The Jerws of Europe before the Second World War (New York, Simon and Schuster) 